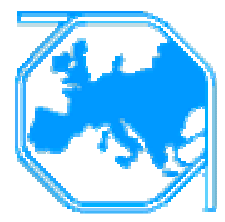

\title{
Container terminal handling quality
}

\author{
Bart W. Wiegmans ${ }^{1 \bullet}$, Piet Rietveld ${ }^{2}$ and Peter Nijkamp ${ }^{2}$ \\ ${ }^{1}$ Department of Innovation Management, Utrecht University, The Netherlands \\ ${ }^{2}$ 'Department of Rgional Economics, Vrije Universiteit Amsterdam, The Netherlands
}

\begin{abstract}
In any service market, the price/quality relationship is of main importance. In the container terminal handling market, quality is important in attracting and retaining customers. Meeting customer needs and delivering high quality for low costs are critical factors for terminals to be successful. Container transport companies are interested in speed and reliability. The time a ship or barge stays in a port must be minimised, and, therefore, the handling of containers must be executed in a fast and reliable way. The operations at the terminal, after the handling of the containers on and off the ship, must be reliable as well. Quantitative information on container terminal quality is hard to obtain. Container terminals are monitoring their quality levels, but the results are not publicly available. Therefore, a literature survey forms the main input for this paper combined with interviews with terminal operators. The aim of this paper is to offer an operational approach for the measurement of the quality of container terminal services. The central research question is; 'Which are critical performance conditions in terms of quality for container terminals?' For the container terminal sector in Europe, 'reliability' is now the number 1 quality aspect in their transport services (including container terminal handling). Quality levels must meet high standards set by container carriers. Costs, incurred by better quality performance cannot be recovered through higher rates. 'Reliability', in terms of meeting container carriers' demand, is thus a critical performance condition for maritime container terminals. An external performance improvement characteristic might be 'flexibility'. Deep-sea ship arrivals are no easy planning task, as weather influences and other problematic developments make the terminal operator's task more difficult. Through strict contracts, all risks of delays and terminal berth congestion are passed onto the terminal operator. This makes 'flexibility' a critical performance condition. A critical performance condition for continental terminal operators is a 'total service'.
\end{abstract}

Keywords: Container terminal; Terminal handling market, Quality of service.

\section{Introduction}

In any service market, the price/quality relationship is of main importance. In the container terminal handling market, quality is important in attracting and retaining customers. In Europe, container carriers do have choices between different container

\footnotetext{
• Corresponding author: B. Wiegmans (b.wiegmans@geog.uu.nl)
} 
ports that can meet their demand. For the terminal operator, this results in the increasing importance of quality and the need to know the needs of (potential) customers. A favourable network position and well-organised processes are no longer sufficient to attract container volumes. Meeting customer needs and delivering high quality for low costs are critical factors. In their supply chain, container carriers are interested in speed and reliability. The time a ship stays in a port must be minimised, and, therefore, the handling of containers must be executed in a fast and reliable way. Minimising the number of damaged or lost containers forms another part of the quality picture. The operations at the terminal, after the handling of the containers on and off the ship, must be reliable as well. Currently, the adoption of innovative handling systems to improve operations has not been signalled in the European container terminal market (Bontekoning, 2002). Quantitative information on container terminal quality is hard to obtain. Container terminals are monitoring their quality levels, but the results are not publicly available. Therefore, a literature survey forms the main input for this paper combined with the interviews with terminal operators. The aim of this paper is to offer an operational approach for the measurement of the quality of container terminal services. The central research question is; 'Which are critical performance conditions in terms of quality for container terminals?' 14 interviews have been carried out in order to offer insight into the actual terminal service quality. For this purpose, the well-known SERVQUAL-model is used. This presents an 'operational' view on the judgement of service quality of container terminals by terminal operators (Parasuraman et al., 1991).

\section{Review of quality of services}

\section{Definition of service}

According to Kotler (1997), a service is any activity or benefit that one party can offer to another that is essentially intangible and does not result in the ownership of anything. Generally, a service can be categorised in terms the following four distinguishing characteristics:

1 intangible;

2 simultaneous production and consumption;

3 heterogeneity;

4 transitory.

Intangible means that 'a service can not fall on your feet' (Grönroos, 1990). Generally, a service is not physical but it is more a 'sort of experience', which means that material possessions do not increase if a service is bought. Intangibility is to be seen as a criterion that varies between 0 and 100 percent. In theory, a pure service is 100 percent intangible, while a pure good is 0 percent intangible or tangible. Simultaneous production and consumption is also referred to as interactive consumption (Lovelock et al., 1981). This means that the consumer needs to be present when the service is produced. In this respect, the consumer is regarded more as a prosumer, i.e. the customer is partly seen also as producer of the service. An example of being a prosumer is an interactive container tracking- and tracing system. The consumer is asked, via the 
Internet, to provide specific information about his shipment to the transport carrier. After sending the required information to the transport carrier, the status of his shipment is provided. The container terminal service is special, in the sense that the service is bought by the management of a container carrier (or barge or rail transport company), but the service is 'experienced' by employees who operate the ships, barges or trains. Because of the participation of the customer in the service production process, it is difficult to standardise services. The customer influences the quality of the service. Requiring the presence of customers in the production of the service implies that the factor time increases in importance. Time may be split into objective time (time in minutes/hours/days) and subjective time (perceived time by the customer). For example, many continental terminals monitor the time that trucks spend at the terminal. The aim is to service the trucks within 30 minutes of arrival. The transitory character of services means that the creation of stocks is impossible. This results in an increased importance for capacity management. Management of supply and demand for services ideally results in minimal unused capacity. This applies to both quiet and busy periods (for example, ship congestion when all berths are occupied or when terminal congestion arises). Generally, waiting time is connected with capacity management and ICTtechnology. The terminal operator might influence the satisfaction with the waiting time on three levels:

1 expectations from the customers about the situation;

2 tolerance of the customer to waiting at the agreed time of delivery of the service;

3 evaluation and valuation of the waiting itself.

'Terminal congestion' imposes a great threat to the efficient operation especially of maritime container terminals. In Rotterdam, for example, the time between the arrival of the maritime container and inland transport is judged to be too long by some terminal customers. This is partly due to veterinary control and the container scan (Nieuwsblad Transport, 2001). Container scan inspection time may add up to five days for rail transport. Road transport does not face this problem: a scan only takes around 12 minutes. All these container terminal service characteristics are important inputs for the service production process.

\section{Service production process}

In the service process, usually the front office of a service organisation interacts directly with customers. This direct interaction is conceded as 'the moment of truth' for the service organisation. The back office is usually not visible for customers. It may be of strategic importance for the service organisation to manipulate the size of its front and/or back office. The conventional service triangle (see Figure 1) consists of three actors (de Vries et al., 1994):

1 the service organisation (back-office);

2 its contact personnel (front-office);

3 its customers. 
The production process of a service can be based on a customer-orientation, a competitor- orientation or a market-orientation. In a customer-orientation, the main objective of the producer of the service may be to fulfil customer needs. He can strive to provide a better price/quality service than his competitor (competitor-orientation), or he can provide his service both customer- and competitor-oriented (market-oriented) (Narver and Slater, 1990; Slater and Narver, 1995). A relatively newly distinguished orientation is process-oriented. In this case, the service is seen as part of the whole supply chain and there is an extensive exchange of information between actors in the supply chain in order to be able to perform all services smoothly.

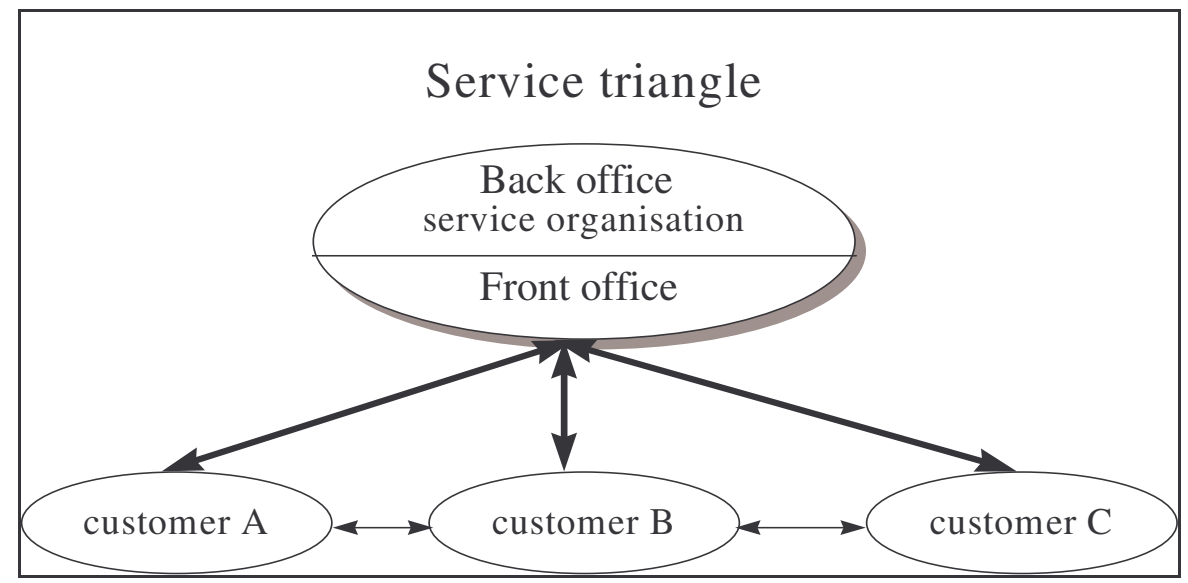

Fig. 1: Conventional service triangle. Source: Based on de Vries et al., 1994.

If the focus is laid on the relation between the terminal operator and its customers, it can be observed that actually four actors are engaged in the service process. There is: the terminal operator; his personnel; the terminal customer; and, the terminal-customer personnel. Thus, instead of the three actors usually involved in the service process, at the container terminal, one extra actor (the terminal-customer personnel) is engaged in the service production process (see Figures 1 and 2). Thus, at the container terminal, two service production processes can be found: one for the terminal customer and one for the terminal-customer personnel.

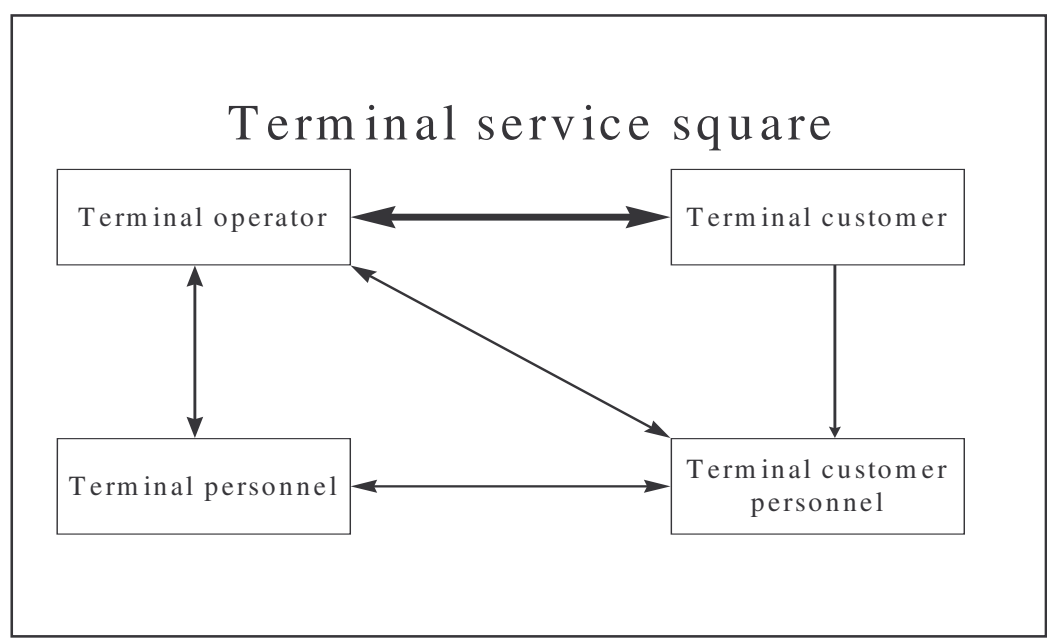

Fig. 2: Terminal service square and actors involved. 


\section{History and background of service quality analysis}

According to Garvin (1984), four phases in the development of quality can be distinguished: I) inspection; II) statistical quality control; III) integrated quality care; IV) strategic quality management. The approach to quality used in this paper is embedded in marketing research. The user (customer) of terminal services fixes the service quality. Generally, in this approach, service quality is defined as 'the difference between expectation and observation'. Research from Parasuraman, Zeithaml, and Berry (1988) shows five dimensions on which users, in general, judge quality. These five dimensions are:

1 tangible matters (e.g. facilities or personnel);

2 reliability (e.g. ability to perform a reliable and accurate service);

3 responsiveness (e.g. willing to help customers and to perform a service quickly);

4 assurance (e.g. knowledge and courteous personnel);

5 empathy (e.g. care for the individual customer).

It is noteworthy that Grönroos (1990) identified only two dimensions of quality: technical quality and functional quality. Technical quality has to do with 'what service is produced?' Functional quality has to do with 'how is the service produced?' And finally De Vries et al. (1994) define Total Quality Control as 'a targeted system to integrate the aim of all groups within an organisation to develop, maintain, and improve quality, in order to organise service and production as efficiently as possible, leading to a completely satisfied customer'. Total Quality Management (TQM) is purely focused on the requirements of customers. On the personal front, people only go back to restaurants that fully satisfy them. Industrial customers, likewise, have a set of requirements and expectations that must be met by the supplier to create repeat business (Bank, 2000). Industrial customers have the same set of emotions as personal customers to being short-changed, disappointed, or cheated. The industrial customers' response to poor service quality is similar: withdrawal of business and buying elsewhere. In traditional quality management, the focus was on acceptable quality levels, 'react' culture, and reducing defects. In TQM, this is no longer enough. TQM is both a philosophy and a set of guiding principles that represent the foundation of a continuously improving organisation (Rampersad, 2001).

In Figure 3, the main features of TQM are given.

Quality can be defined as 'fully satisfying agreed customer requirements at the lowest internal costs' (Bank, 2000). In general, customers perceive terminal services to be low quality, resulting in not completely satisfied customers. Quality management of container terminals is still quite traditional, which is reason enough for an increasing number of container carriers to start operating their own dedicated maritime container terminals. Customers of continental container terminals, dissatisfied with the service quality, might return to using single-mode road transport. When trying to accommodate customer needs, a complicating factor for the continental terminal operator is the wide variety of terminal customers. Almost each terminal customer needs its own terminal service quality performance. Transport research in the EU (IQ, 1997; EU, 1997, TERMINET, 1998) shows the following important quality elements concerning transport: time, reliability, flexibility, qualification, accessibility, control, handling price, frequency, speed, long-term planning, management, and safety and security. A 
structured approach towards terminal service quality is offered by the SERVQUALmodel (see Sections 4 and 5).

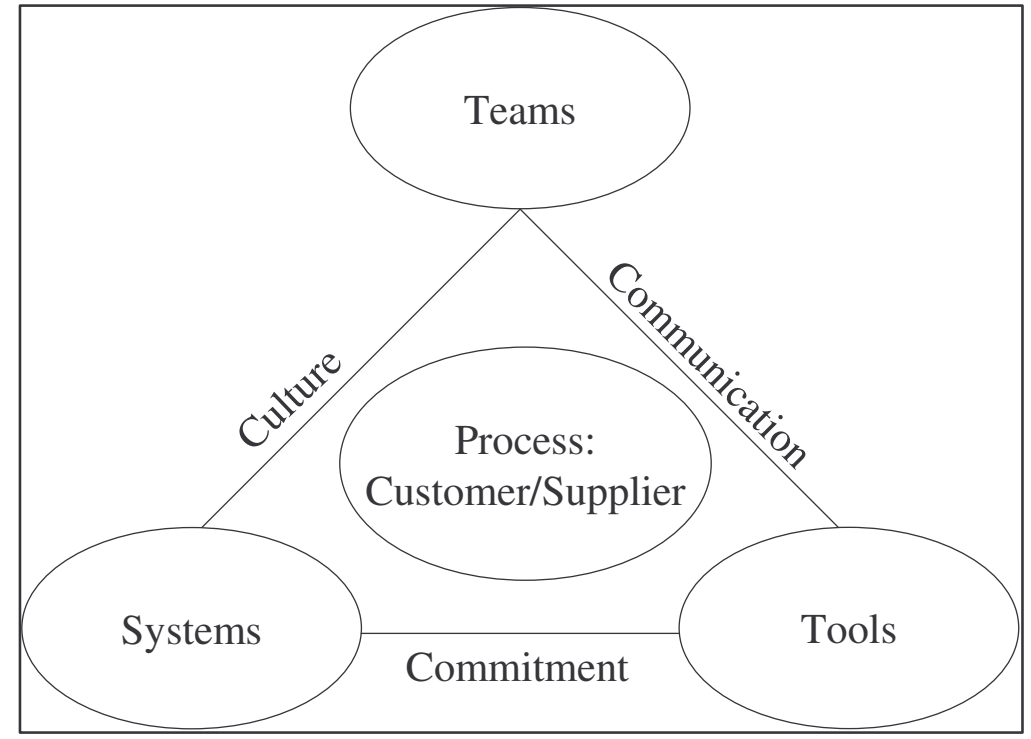

Fig. 3. Total Quality Management Model

Source: Oakland, 1994.

\section{Container terminal service quality}

\section{Measurement of container terminal services}

The measurement of service quality can, in general, be done with regard to three aspects: search, experience, and credence attributes. 'Search attributes' are quality features that can be identified by the customer before the purchase of a certain service. 'Experience attributes' are features that can only be disclosed during or directly after the consumption of a certain service. Finally, 'credence attributes' are features that can not be identified by customers, neither before nor after the consumption of the service. Salient Multi-Attribute Research Technique (SMART) is a well-known research technique to measure service quality (de Vries et al., 1994). SMART enables the identification of service elements that, according to customers, need the highest priority when improving the service. Another research technique is called conjunct research (de Vries et al., 1994). In this technique, in-depth interviews provide the service attributes with the corresponding levels of service. Each attribute is connected with a number of service levels and each customer is asked to evaluate certain imaginary services in terms of these levels. This technique has provided the basis for the interviews with terminal operators.

In order to measure terminal service quality, a distinction must be made between the different terminal service elements. At a container terminal, the single most important activity is the movement of containers, whereas the secondary function is storage. This primary function of a container terminal can be divided into different parts: loading; unloading; and, direct transshipment of containers. Transshipment is the unloading of a 
Transport Unit (TU) directly followed by the loading of the TU onto another transport means. Handling is the unloading of a TU followed by the temporary storage of the TU at the terminal, which is followed ultimately by loading the TU onto another transport means for further transport. At a container terminal the following central activities can be found:

1 ship-oriented services: discharging the ship, loading the ship, direct transhipment, storage of container/warehousing, and container groupage

2 yard-oriented services;

3 other terminal services: manufacturing, renting/leasing/selling services, collection/distribution of container, physical transport of container, container monitoring, and other services.

Bowersox et al. (1986) view handling as one of the most costly aspects of logistic channel performance, and thus the objective is to reduce handling operations in the logistic chain to an absolute minimum. This creates an extra dimension concerning quality: there is a tendency to minimise terminal handling to a minimum, stressing the importance of quality even more. The distinction between services is necessary in order to be able to determine which services are important or should be important to the terminal operator. In addition to this, performance measures should be developed to be able to monitor the performance of the terminal with respect to the chosen quality aspects.

\section{Actors in the service process and quality}

Besides the services provided the customers are important, because, in the final analysis they must judge the quality of the services offered. If the focus is placed on terminal customers of both maritime and continental terminals, four main groups of customers can be distinguished:

1 container carriers (deep-sea shipping companies);

2 transport companies (rail-, road-, barge-, and short-sea transport companies);

3 importers/exporters (intermediaries, such as stevedores, ship brokers, shipping agents and forwarders);

4 shippers (companies that send and receive the freight).

The main customer groups must be identified in order to be able to determine the weight that must be placed on the judgements of the different groups. The services that are provided can be grouped according to type of customers, importance of different sales categories, type of container (process) or transport mode (network). Usually, terminal operators are not entirely clear about their customers, and therefore offer a broad package of functions for the sake of risk-spreading and widening the operating base (i.e. many potential customers). In the continental terminal market, much is expected from new generation terminals (Bontekoning and Kreutzberger, 2001). These types of terminals are expected to deliver an improvement of the cost-quality ratio of terminal operations (Konings and Kreutzberger, 2001).

The terminal service buying process can be divided into three activities: 
1 pre-purchase phase (problem definition, information collection, and evaluation of alternatives);

2 consumption of the terminal service;

3 post-purchase phase (evaluation of the terminal services).

In the pre-purchase phase, the actors are the terminal operator and the terminal customer. Usually, the terminal-customer personnel, the terminal personnel and the terminal operator consume the terminal service. The terminal customer and his personnel execute the evaluation of the service. Generally, the customers' management does not have an obligation to be present in person. The service delivered to the terminal customers is quite homogeneous and there is no need for participation of the terminal customers' management in the service production process. Furthermore, the customer service is intangible, there is no need for simultaneous production and consumption, and the objective terminal transit time is highly important.

\section{Terminal customers and quality}

In Figure 4, the main elements influencing, and following from, terminal service quality are depicted. The terminal customer provides the terminal operator with requirements concerning the desired terminal service. In particular, flexibility requirements have been growing in importance during the past years (Kuipers, 1999). The terminal customer consists of two elements: the management (back office) and the employees (front office) who are present when the service is produced at the container terminal. The terminal operator also consists of two sub-elements: front office and back office. This results in four groups that may have different expectations and observations about terminal service quality. This means that both the terminal customer's front- and back office must judge the quality of the terminal service. An additional complicating factor is that for the terminal operator the inclusion of the supply chain (or marketing channel) approach in the quality delivery is extremely important, because it is the channel, not the terminal operator that actually delivers the products and services to the final customers. Without channel coordination, it may be even harder to achieve an adequate terminal service performance level.

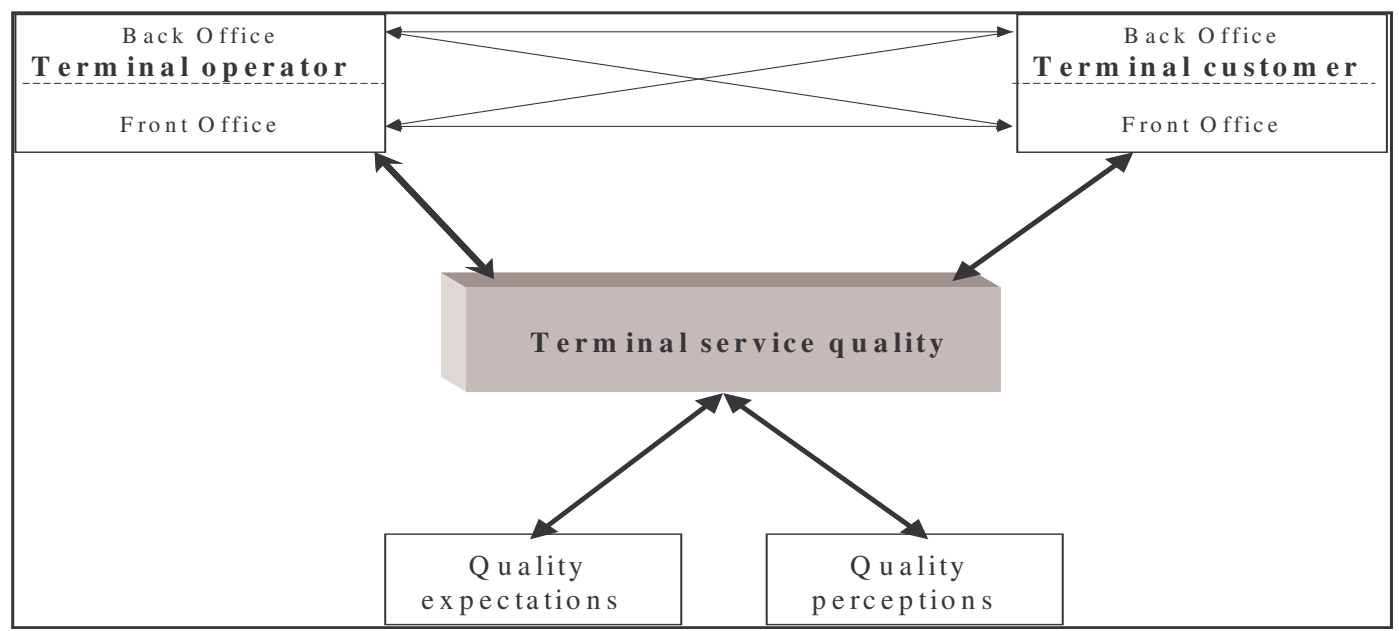

Fig. 4. Terminal service quality environment Source: Based on de Vries et al., 1994. 


\section{Costs of service quality}

Achieving quality services costs money. The costs can be made in different parts of the service production process. A useful concept in analysing the cost of terminal service quality may be that of value density (value per unit weight). The value density reflects the relative importance of the container in transit and inventory in the logistics system (Magee et al., 1985). In any business, this suggests that it might be preferable to stock low-value items rather than high-value items. The terminal operator can also use this knowledge: the higher the value of the container the operator is handling, the more important reliability and speed become. Generally, costs of service quality comprise (de Vries et al., 1994):

1 prevention costs (e.g. training programmes);

2 inspection costs (e.g. costs of quality tests);

3 internal repair costs (e.g. costs to repair errors before the service reaches the customer);

4 external repair costs (e.g. costs to repair errors after the service has reached the customer).

5 Lost sales (these do not result in direct costs, but may well represent the highest damage to a company delivering poor service quality.

Delivering good quality services only requires inspection costs and prevention costs, whereas, in the case of poor service quality, costs also consist of internal and external repair costs and lost sales. The total container handling service costs should always be placed in the perspective of the total marketing channel costs. The terminal handling costs depend - as well as on the desired quality level - on container characteristics (value), size of shipment (volume), weight, handling difficulty, density, buying of additional terminal services, and transport distance to and from the terminal. The SERVQUAL-model is used as framework to analyse the terminal service quality.

\section{The SERVQUAL-model}

The SERVQUAL-model of Parasuraman, Zeithaml, and Berry (1985) represents a useful instrument to structure the above-mentioned elements of quality research. In this model, the difference between customer expectations and observations (valuations or judgements) is measured. If the expectation of the customer is greater than his observation, there is a lack of quality. Quality is delivered when the observation is equal to the expectation. More quality is delivered if the observation of the customer is greater than his expectation. The expectations must be carefully dealt with, as expectations can be low. In this respect, it is better to focus on the aspirations rather than on expectations. In the terminal interviews, the expectations of terminal operators about terminal customers expectations have been used as a proxy for the important quality elements. The objectives of terminal operators may be stated as cost minimisation/profit maximisation, capacity-oriented and realising political goals (e.g. concerning the environment, enhancement of status and role). Given those mixed approaches towards terminal operations, the importance of terminal quality measurement and improvement is even higher. In particular, the terminal operators may accomplish the increase in terminal service performance and must then define 'target' quality levels. The terminal 
operator should translate the customers' quality requirements into performance statements. The set of quality questions below served as input for the interviews (See Table 1). Knowledge about customer's expectations and observations of the delivered container terminal service quality is the result. Table 1, inspired by Parasuraman et al., gives the terminal operators' overall judgement of quality elements (with 7 being the most important). It has not been possible to interview terminal customers. Testing the SERVQUAL-model with terminal customers is thus an important item for further research. This would make it possible to compare the terminal operators' expectations with terminal customers judgements of service quality.

Table 1: Quality judgements of container terminal operators.

\begin{tabular}{|c|c|c|}
\hline $\begin{array}{l}\text { Quality } \\
\text { dimension }\end{array}$ & Questions & $\begin{array}{l}\text { Overall } \\
\text { importance }\end{array}$ \\
\hline \multirow[t]{4}{*}{ Tangibles } & $\begin{array}{l}\text { 1. excellent terminals will have modern-looking (and performing) } \\
\text { equipment }\end{array}$ & 5 \\
\hline & $\begin{array}{l}\text { 2. the physical facilities at excellent terminals will be visually } \\
\text { appealing }\end{array}$ & 5 \\
\hline & $\begin{array}{l}\text { 3. employees of excellent terminals will be neat-appearing (look } \\
\text { smart) }\end{array}$ & 5 \\
\hline & $\begin{array}{l}\text { 4. Materials associated with the service (such as pamphlets or } \\
\text { statements) will be visually appealing in an excellent terminal }\end{array}$ & 5 \\
\hline \multirow[t]{5}{*}{ Reliability } & $\begin{array}{l}\text { 5. when excellent terminals promise to do something by a certain } \\
\text { time, they will do so }\end{array}$ & 7 \\
\hline & $\begin{array}{l}\text { 6. when customers have a problem, excellent terminals will show a } \\
\text { sincere interest in solving it }\end{array}$ & 7 \\
\hline & 7. excellent terminals will perform the service right the first time & 7 \\
\hline & $\begin{array}{l}\text { 8. excellent terminals will provide their services at the time they } \\
\text { promise to do so }\end{array}$ & 7 \\
\hline & 9. excellent terminals will insist on error-free records & 7 \\
\hline \multirow[t]{4}{*}{ Responsiveness } & $\begin{array}{l}\text { 10. employees of excellent terminals will tell customers exactly when } \\
\text { services will be performed }\end{array}$ & 6 \\
\hline & $\begin{array}{l}\text { 11. employees of excellent terminals will give prompt service to } \\
\text { customers }\end{array}$ & 7 \\
\hline & $\begin{array}{l}\text { 12. employees of excellent terminals will always be willing to help } \\
\text { customers }\end{array}$ & 7 \\
\hline & $\begin{array}{l}\text { 13. employees of excellent terminals will never be too busy to } \\
\text { respond to customer requests }\end{array}$ & 6 \\
\hline \multirow[t]{4}{*}{ Assurance } & $\begin{array}{l}\text { 14. the behaviour of employees of excellent terminals will instil } \\
\text { confidence in customers }\end{array}$ & 6 \\
\hline & $\begin{array}{l}\text { 15. customers of excellent terminals will feel secure in their } \\
\text { transactions }\end{array}$ & 7 \\
\hline & $\begin{array}{l}\text { 16. employees of excellent terminals will be consistently courteous } \\
\text { with customers }\end{array}$ & 6 \\
\hline & $\begin{array}{l}\text { 17. employees of excellent terminals will have the knowledge to } \\
\text { answer customer questions }\end{array}$ & 7 \\
\hline \multirow[t]{5}{*}{ Empathy } & 18. excellent terminals will give customers individual attention & 6 \\
\hline & $\begin{array}{l}\text { 19. excellent terminals will have operating hours convenient for all } \\
\text { their customers }\end{array}$ & 6 \\
\hline & $\begin{array}{l}\text { 20. excellent terminals will have employees who give customers } \\
\text { personal attention }\end{array}$ & 5 \\
\hline & 21. excellent terminals will have the customers' best interests at heart & 7 \\
\hline & $\begin{array}{l}\text { 22. the employees of excellent terminals will understand the specific } \\
\text { needs of their customers }\end{array}$ & 7 \\
\hline
\end{tabular}

Note: Importance is scored from 1-7.

Source: own research. 
The scores in Table 1 correspond with the overall results of the interviews. The results show that most quality aspects are quite important to terminal operators. Reliability, responsiveness, and assurance are particularly important to terminal operators. Tangibles and empathy are relatively less important to the terminal operator. It might be kept in mind that the terminal management has been interviewed that deals with customer's management. If terminal customers' personnel is interviewed, the scores might be different and tangibles and empathy are likely to be more important. In Section 4 and 5, the results will be further analysed according to terminal type.

\section{Maritime container terminal service quality}

\section{Quality judgement history}

In general, container terminal services have no extensive history concerning quality measurement. Some research has been carried out on quality aspects in the field of transport mode comparison and also in the field of logistics. In that field, it has been shown that, in the past, average delivery time was the most important customer service element in correlation with customer satisfaction (see also Table 2). This table indicates the importance of different quality aspects to customers. It not only applies to transport or logistics companies, but also to terminal operators. In the following sections, the results from the terminal interviews will be presented. The maritime service production process will be explored and the measurement of the quality of the services is presented.

Table 2: Contribution of customer service elements of logistics to customer satisfaction.

\begin{tabular}{lc}
\hline Customer service elements & Correlation Coefficient (1) \\
\hline average delivery time & 0.76 \\
delivery time availability & 0.72 \\
order status information & 0.67 \\
rush service & 0.59 \\
order methods & 0.56 \\
action on complaints & 0.56 \\
accuracy in filling orders & 0.46 \\
returns policy & 0.44 \\
billing procedure & 0.39 \\
\hline
\end{tabular}

Note: (1) Correlation between service element and customer satisfaction.

Source: Perreault and Russ, 1976.

\section{Quality and price setting}

Some terminal productivity measures may be helpful for the terminal operator to better quantify handling service benefits (improved quality) and costs: firms with high product value have high transport quality demands; large firms with strong bargaining power have a high transport quality; firms located in large clusters have high transport 
quality; and, the willingness to pay correlates positively with the quality level (Klaesson, 2001). Better quality might thus result in more pricing power for the terminal operator. The benefits for the terminal operator of improved quality management are difficult to quantify, because of the trade-off between costs and quality. This trade-off consists of three variables: service variability; the relative importance of handling costs as compared with total transport costs; and, the nature of the value-added chain (Magee et al., 1985). A broader terminal service package will require significant costs to obtain a high service level. Handling costs versus total transport costs reflects the viability of the different transport options. Finally, the value-added chain decides on the speed with which the different goods need to be handled by the terminal operator. In general, the demand for container transport is inelastic (Coyle, 1994). Thus, container rate reductions (e.g. terminal service charges) will not increase the demand for container transportation dramatically. However, demand is price sensitive on a modal and specific-carrier basis (e.g. combined transport versus single-mode road transport). The interviewed terminal operators indicate that price variability in the continental container terminal market is limited. In the maritime terminal market, handling prices do vary on the port level in Europe (inside ports the competition between terminal operators is less intense). This means that investments in quality in the continental container terminal market, must lead to reduced costs to increase profit levels for container terminal operators.

\section{Maritime service production process}

For the maritime container terminal operator, ship services are the most important. All services are offered (ship, yard, and other), but the handling service is of prime importance. The container carriers are the main customers and the central focus is on the quality of service that they receive. The management of the terminal deals with the management of the container carrier, in order to define the desired service levels. At the end of the service chain, the terminal operating personnel and the container carrier operating personnel are present at the terminal handling service delivery. The main characteristics of the maritime container terminal service are presented below. Maritime terminals are open 24 hours a day, 365 days a year. The average transit time for a container is between 48 and 96 hours through a maritime terminal. According to the terminal operators, in the service production process, the reliability of the service is most important for them. Compared with the results from Perrault and Russ (1976), 'average delivery time', 'time availability', and 'rush service', have decreased in importance, while 'reliability' (e.g. accuracy, action on complaints) has increased in importance. See Table 3 for an overview of the main maritime container terminal interview results.

Table 3: Service in the maritime container terminal market.

\begin{tabular}{ll}
\hline Variable & Type \\
\hline Kind of services & Ship, yard, other \\
Container terminal transit time & $48-96$ hours \\
Operating hours & $24 / 7$, all year \\
Critical performance condition & Reliability \\
\hline
\end{tabular}

Source: Terminal interviews, 2002. 


\section{Measurement of maritime handling quality}

The maritime container terminal quality importance has been tested on 5 quality dimensions. These dimensions are: tangibles - the appearance of the physical facilities; reliability - the ability to provide the promised service; responsiveness - the willingness to help customers; assurance - the knowledge of the personnel; and, empathy - the caring for terminal customers. The interviewed terminal operators have been asked to divide 100 points between these five items (see Table 4 for an overview).

Table 4. Quality importance in the maritime container terminal market.

\begin{tabular}{l|c}
\hline Quality indicator & Share (\%) \\
\hline Tangibles & 20 \\
Reliability & 30 \\
Responsiveness & 15 \\
Assurance & 20 \\
Empathy & 15 \\
\hline
\end{tabular}

Source: Terminal interviews, 2002.

The interviews show that 'reliability' is of main importance to maritime terminal operators. The main finding for maritime container terminals is that all quality variables are important, but 'reliability' is the most important one.

\section{Terminal services and quality}

Several characteristics of the maritime container terminal service have been tested in the interviews. All promotion channels are used in order to attain and retain customers. Overall, the container terminals are satisfied with their location. The percentage of containers that is not handled according to customer requirements is far less than 1 percent, and the conflicts over false handlings are solved to the maximum extent possible. Maritime container terminal customers expect excellent service, therefore, quality costs are concentrated at the beginning of the internal service production process. Costs are made in order to prevent internal quality defects. Terminal performances measured by the maritime operators are crane performance, container damage, the performance of straddle carriers, and that of other transport modes (besides deep-sea). However, maritime terminal customers are also interested in channel performance, suggesting that terminal operators might start measuring channel performance, in addition to internal performance. The attitude of maritime terminals should change from production-oriented to customer-oriented. A table with the main scores (in the range 1-7) of maritime terminals, concerning the SERVQUAL-model is not given, because the responses on this part of the questionnaire were insufficient. The main result from the limited number of interviews shows that maritime terminals claim that all quality aspects are important. 


\section{Conclusion}

Several hypotheses have been tested in order to test and fine-tune the main findings in the interviews. The main conclusions for maritime container terminals are presented here:

1 better educated personnel, shorter container terminal transit time, better handling performance, and quality measurement may improve the service handling;

2 reliability is the most important quality criterion for the container terminal.

The most critical performance condition for maritime container terminal operators in terms of quality is thus 'reliability'. Handling speed, information and communication are quoted as important tools to improve the quality performance of maritime container terminals. Reliability of the terminal service should be 'enlarged' to match the reliability of the container handling service in the total perspective of the value chain of the container carriers.

\section{Continental container terminal service quality}

\section{Quality judgement}

In the annual report of RENFE (1998) there is also a short section on quality measurement concerning intermodal freight transport including the use of continental rail container terminals.

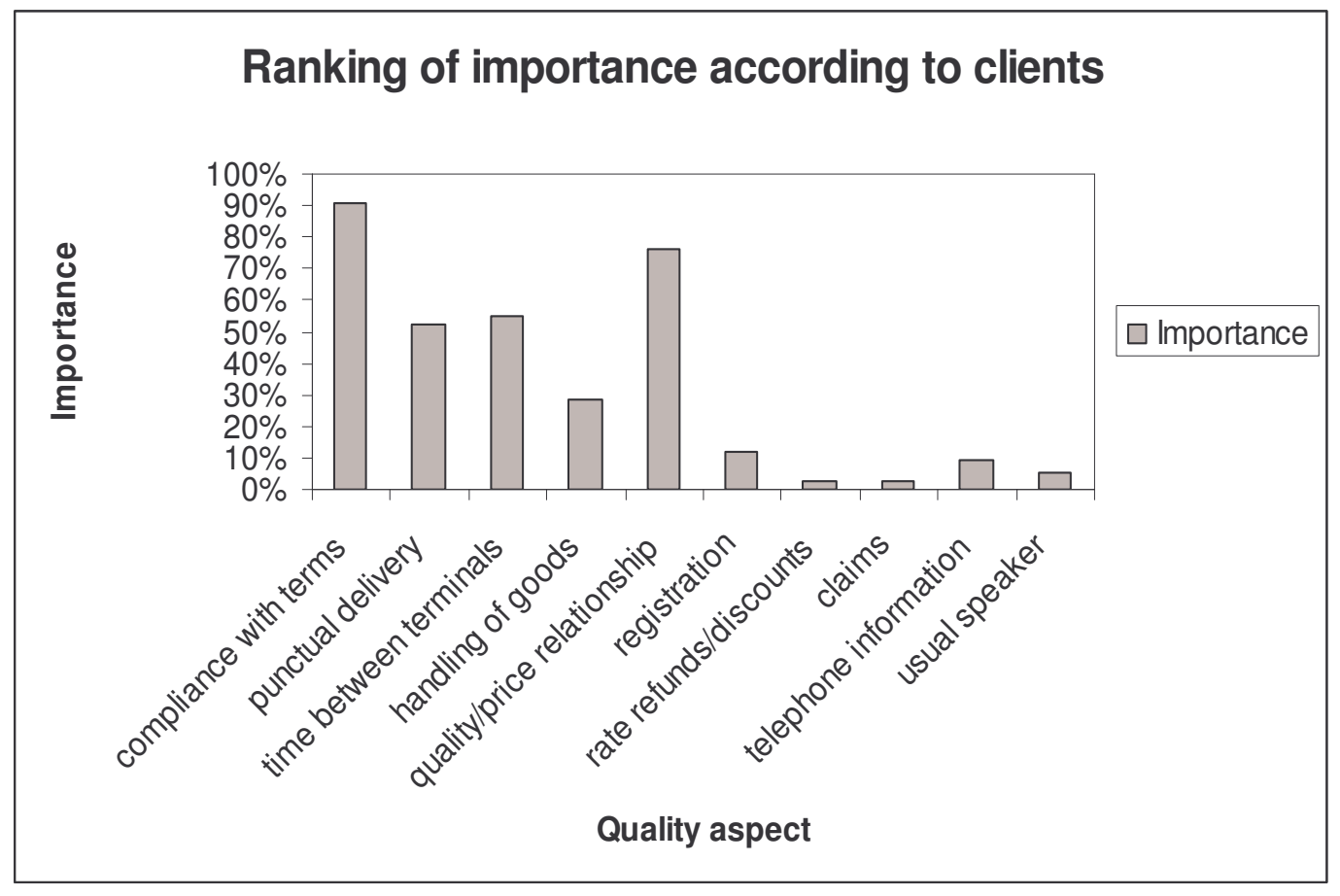

Fig. 5 Quality aspects and customer judgement of rail service.

Note: Usual speaker refers to usual contact person.

Source: Annual report RENFE, 1998. 
This quality judgement by customers concerns rail services, including the use of container terminals. It shows that, according to clients, 'compliance with terms' and 'quality/price relationships' are the most important quality aspects. 'Compliance with terms' may also be stated as 'reliability'.

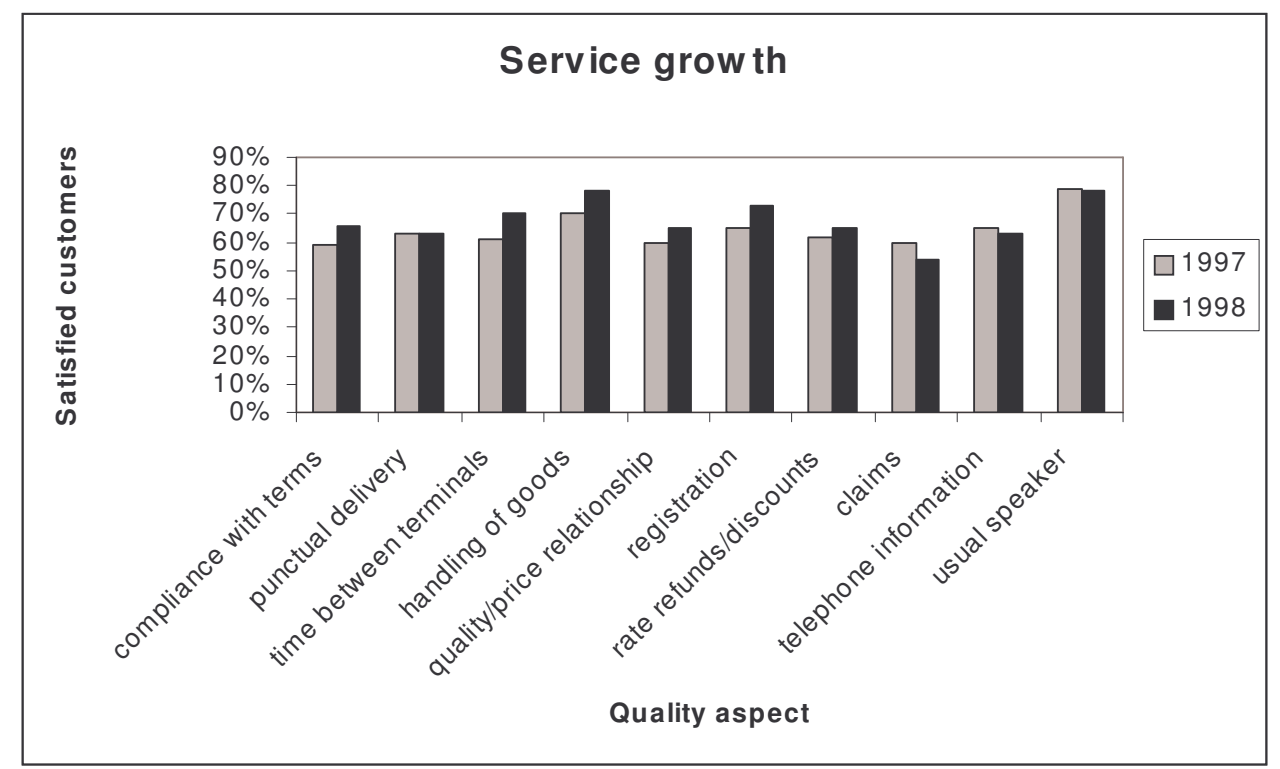

Fig. 6. Development of judgements of quality characteristics of rail service.

Source: Annual report RENFE, 1998.

Figure 6 depicts the development of the quality judgement of RENFE-customers from 1997 to 1998. In general, a well-performing service company may reach levels of 95-99 percent satisfied customers.

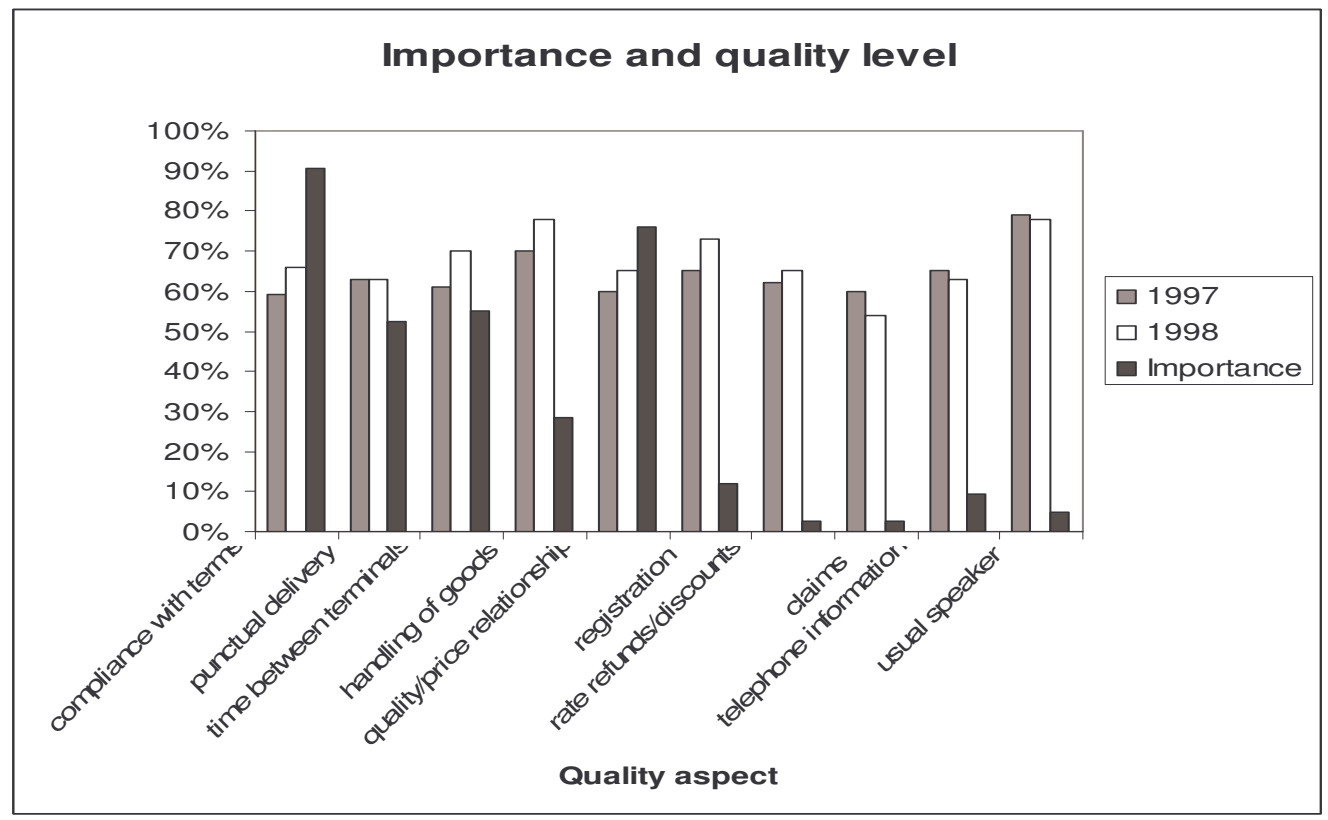

Fig. 7. Importance of quality characteristics and corresponding judgements.

Source: Annual report RENFE, 1998. 
Figure 5 shows that the quality aspects that are the most important ('compliance with terms' and 'quality/price relationship') are also those where customers are least satisfied. In general, it is more important for operators to perform better in aspects that are more important to customers. Figures 6 and 7 provide insight into the expectations of and importance expressed by, customers concerning performance and into the actual performance of continental rail services, including terminals, in Spain. This background on the quality performance of RENFE will be related to the results of the interviews in the next sections.

\section{Continental service production process}

Most continental terminal operators who have been interviewed have large customer bases, and most of the customers are located close to the terminal. The terminal management deals with the customers' management, in order to define the desired service levels. Ultimately, the terminal operating personnel and the customers' operating personnel are present at the terminal handling service delivery. The distance between terminal management and operating personnel is much smaller for rail and barge terminals, than it is for maritime terminals. The operating hours for barge terminals show a mixed picture, ranging from Monday 05.00 - Saturday 12.00 every week to 24/7, 365 days a year. The average container terminal transit time for barge terminals is 48 hours and for rail terminals 73 hours. In the service production process, reliability of the service is most important (see Table 5 for an overview of the main continental container terminal results).

Table 5. Service in the continental container terminal market.

\begin{tabular}{lll}
\hline Variable & Continental barge & Continental rail \\
\hline Kind of services & Barge, yard, other & Rail, yard, other \\
Average container terminal transit time & 48 hours & 73 hours \\
Operating hours & Most 24/7, all year & Mon. 05.00-Sat. 12.00 \\
Critical performance conditions & Reliability & Reliability \\
\hline
\end{tabular}

Source: Terminal interviews, 2002.

\section{Measurement of continental handling quality}

The continental barge and rail terminal performance has been tested on the 5 quality dimensions mentioned above (see Table 6 for an overview).

Table 6 shows that 'reliability' is of main importance to both barge and rail terminal operators. The main finding for continental barge container terminals is that the differences between the quality variables are not large. This means that all quality variables are important, and 'reliability' must be perfect. Continental rail terminals, on the contrary, are strongly focussed on 'reliability' and less on the other quality aspects. This might be due to the great chance of disruption in the rail transport chain. 
Table 6. Quality importance in the continental container terminal market

\begin{tabular}{lcc}
\hline Variable & Barge & Rail \\
\hline Tangibles & 13 & 9 \\
Reliability & 25 & 55 \\
Responsiveness & 22 & 13 \\
Assurance & 20 & 12 \\
Empathy & 21 & 11 \\
\hline
\end{tabular}

Source: Terminal interviews, 2002.

\section{Terminal services and quality}

Several characteristics of the maritime container terminal service have been tested in the interviews. All promotion channels are used in order to attract and retain customers. Furthermore, the terminal management frequently visits potential and current customers. Overall, the container terminals are satisfied with their location and with the accessibility by barge, road, and rail. The percentage of containers that is not handled according to customer requirements is less than 1 percent for rail terminals, and the conflicts over these false handlings are solved where possible. For barge terminals, the false handlings are between 1 and 3 percent, with one terminal reaching almost 10 percent (interviews with terminal operators, 2002). Barge and rail terminal customers expect 'reliability', 'good price', and 'added value'. Terminal performance measured by the barge operators concern barge on-time performance, and customer pre- and endhaulage on-time performance. Rail terminals measure the on-time performance of trains (departures) and trucks (percentage handled within 30 minutes).

Table 7 shows that rail and barge terminals rate the quality dimensions almost equally. All differences are not more than one point. If Tables 6 and 7 are combined, it shows that barge terminals are focussed on 'offering a total service package' of good quality. 'Tangibles' are relatively less important to barge terminal operators. Rail terminal operators claim that all quality dimensions are important, but if a choice must be made; 'reliability' is very important for their overall performance.

\section{Conclusion continental terminals}

The main conclusions for continental terminals are:

1 better educated personnel, shorter container terminal transit time, better handling performance, and quality measurement will not enable a price raise per handling. This means that quality improvements must come down into cost reductions. This is even more complicated as the investment costs for improved quality are concentrated at the terminal, while most advantages occur in the networks (Trip and Kreutzberger, 2002);

2 'reliability' is the most important quality criterion for the container terminal;

3 customer satisfaction is influenced by terminal transit time, opening hours, information availability, complaint handling, do what is promised, accuracy, connections, and service quality. 
The most critical performance conditions for continental terminal operators are offering a 'total service package' for barge terminals and offering 'reliability' to rail terminal operators.

Table 7. Quality judgements of continental container terminals.

\begin{tabular}{|c|c|c|c|}
\hline Quality dimension & Barge terminals & Rail terminals & $\begin{array}{l}\text { Difference } \\
\text { Barge-Rail }\end{array}$ \\
\hline 1. Tangibles: equipment & 5 & 5 & $=$ \\
\hline 2. Tangibles: facilities & 5 & 5 & $=$ \\
\hline 3. Tangibles: clothes & 5 & 5 & $=$ \\
\hline 4. Tangibles: promotion & 4 & 5 & -1 \\
\hline 5. Reliability: promise & 7 & 7 & $=$ \\
\hline 6. Reliability: solve & 7 & 7 & $=$ \\
\hline 7. Reliability: $1^{\text {st }}$ time & 7 & 7 & $=$ \\
\hline 8. Reliability: on-time & 7 & 7 & $=$ \\
\hline 9. Reliability: mistakes & 7 & 6 & +1 \\
\hline 10. Responsiveness: tell & 7 & 6 & +1 \\
\hline 11. Responsiveness: adequate & 7 & 7 & $=$ \\
\hline 12. Responsiveness: always & 7 & 7 & $=$ \\
\hline 13. Responsiveness: busy & 6 & 6 & $=$ \\
\hline 14. Assurance: behaviour & 6 & 7 & -1 \\
\hline 15. Assurance: safe & 7 & 6 & +1 \\
\hline 16. Assurance: careful & 6 & 6 & $=$ \\
\hline 17. Assurance: knowledge & 7 & 6 & +1 \\
\hline 18. Empathy: individual & 7 & 6 & +1 \\
\hline 19. Empathy: open & 5 & 6 & -1 \\
\hline 20. Empathy: personal & 5 & 5 & $=$ \\
\hline 21. Empathy: customer & 7 & 6 & +1 \\
\hline 22. Empathy: needs & 7 & 7 & $=$ \\
\hline
\end{tabular}

Note: The quality dimensions on the left-hand side correspond with the extensive described numbers in Table 8.1.

Source: Terminal interviews, 2002.

\section{Conclusion}

\section{Conclusion for maritime terminals}

According to past transport research, average delivery time was judged to be of main importance. The interviews have proven that this has changed for the container terminal sector in Europe. 'Reliability' is now the number 1 quality aspect in their transport services (including container terminal handling). As transport services are, in general, price inelastic, container handling price reductions will not generate a dramaticallyincreased demand for container handling. The market is very competitive on a port-byport basis. Quality levels must meet high standards set by the container carriers. Costs, 
incurred by better quality performance cannot be recovered through higher rates. 'Reliability', in terms of meeting container carriers' demand, is thus a critical performance condition for maritime container terminals. An external performance improvement characteristic might be 'flexibility'. Deep-sea ship arrivals are no easy planning task, as weather influences and other problematic developments make the terminal operator's task more difficult. Through strict contracts, all risks of delays and terminal berth congestion are passed onto the terminal operator. This makes 'flexibility' a critical performance condition. Measuring 'total' container channel performance, through an increased number of terminal performance measures, might help to improve the reliability of container terminals. Most maritime container terminals measure performance on the basis of their terminal; container carriers are interested in channel performance: Is container $\mathrm{X}$ reliably transported from point $\mathrm{A}$ to $\mathrm{B}$ in the agreed timeframe? Internal terminal performance measures must therefore be extended with external terminal performance measures. These external performance measures measure the container carriers' on-time performance. Critical internal performance improvement characteristics for terminal operators are handling speed, information and communication.

\section{Conclusion for continental terminals}

Single-mode transport is the reference point on which the terminal operators base their price. They must ideally meet the single-mode road transport price, or even better, be cheaper. A critical performance condition for continental terminal operators is a 'total service assortment'. The total service, including pre- and end-haulage (logistics solution) is important, not the container handling only. Secondary services, like container repair or cleaning, further increase sales. The competitive position of continental (mainly barge) terminals is stronger than that of maritime and rail terminals. A large customer base and a broad service package offers opportunities to make money. Another important performance condition for continental container terminals is the 'small distance' between the operating personnel and the management. Some terminals measure quality performance, and others do not. It is not possible to recover the extra quality control costs through higher prices. Individualised attention and caring for customers may be as good as making the effort to measure quality performance. Due to the limited scale of continental barge and rail terminals, it is often possible to work without a professional quality performance measurement system. However, if the container terminal grows larger, an automated system to monitor quality performance might be implemented. 'Reliability' is a critical performance condition for continental terminal operators, especially for rail terminals, due to the great likelihood of disruption of the system flow, in the rail part of the transport solution. Barge terminals, in order to determine their own quality, but also in order to determine the total channel performance, monitor the start and the end of the trip of a container. The interviews indicated that some barge terminals may be further advanced in measuring transport channel performance than maritime and rail terminals. 


\section{References}

Bank, J. (2000) The essence of total quality management, Prentice Hall, Harlow

Bontekoning, Y.M. (2002) Towards new-generation terminal operations: identifying implementation obstacles, Delft University Press, Delft

Bontekoning, Y.M., and Kreutzberger, E. (2001) "New-generation terminals", TRAIL, Delft

Bowersox, D.J., Closs, D.J., and Helferich, O.K. (1986) Logistical management, Macmillan Publishing Company, New York

Coyle, J.J., Bardi, E.J., and Novack, R.A. (1994) Transportation, fourth edition, West Publishing Company, St. Paul/Minneapolis

European Commission (1997) Intermodal quality and performance indicators, Deliverable 1, INRETS

Garvin, D.A. (1984) "Product quality: an important strategic weapon", Business Horizons: 40-43

Grönroos, C. (1990) Service management and marketing, Lexington Books, D.C. Health and Company, Lexington, Massachusetts

Intermodal Quality (1997) "The quality of terminals", Executive summary, In: European Commission Intermodal quality and performance indicators, Brussels

Klaesson, J. (2001) A study of localisation economics and the transport sector, Jonkopping International Business School

Konings, J.W., and Kreutzberger, E. (2001) "Towards a quality leap in intermodal freight transport", TRAIL, Delft

Kotle,r P. (1997) Marketing management: analysis, planning, implementation and control, Prentice Hall International Inc., Upper Saddle River, New Jersey

Kuipers, B. (1999) Flexibiliteit in de Rotterdamse havenregio, Uitgeverij Eburon, Delft

Lovelock, C.H., Langeard, E., Bateson, J.E.G., and Eiglie,r P. (1981) "Some organisational problems facing marketing in the service sector", In: Marketing of services, Donnelly, J.A. and. George, W.R (eds)

Magee, J.F., Copacino, W.C. and. Rosenfeld, D.B. (1985) Modern logistics management integrating marketing, manufacturing and physical distribution, John Wiley and Sons, New York

Narver, J.C. and Slater, S.F. (1990) "The effect of a marketing orientation on business profitability", Journal of Marketing, vol 54, pp. 20-35

Nieuwsblad Transport (2001) several articles, Nieuwsblad Transport, Rotterdam

Oakland, J.S. (1994), Total quality management: the route to improving performance, ButterworthHeinemann, Oxford

Parasuraman, A., Zeithaml V.A. and Berry L.L. (1985) “A conceptual model of service quality and its implications for future research", Journal of Marketing, vol. 49, pp. 41-50

Parasuraman, A., Zeithaml V.A. and Berry L.L. (1988) "Servqual: a multiple-item scale for measuring consumer perceptions of service quality", Journal of Retailing, vol. 64, pp. 12-40

Parasuraman, A., Zeithaml V.A. and Berry L.L. (1991) "Refinement and reassessment of the servqualscale", Journal of Retailing, vol. 67, pp. 420-450

Perreault jr., W.D., and Russ, F.A. (1976) "Physical distribution service in industrial purchase decisions", Journal of Marketing, vol. 40, p. 8

Rampersad, H.K. (2001), Total Quality Management, Springer, Berlin

RENFE (1998), Annual report 1997, RENFE

Slater, S.F and Narver J.C. (1995) Market orientation and the learning organisation, Journal of Marketing, vol, 59, pp. 63-74

TERMINET (1998), Indicators and criteria for new-generation bundling, terminals and terminal nodes, Delft University of Technology, Delft

Trip, J.J. and Kreutzberger E. (2002) Complex bundling networks and new-generation terminals: a synthesis, Delft University Press, Delft

Vries jr, W. de, Kasper H. and Van Helsdingen P.J.C. (1994) Dienstenmarketing, Educatieve Partners Nederland BV, Houten 